\title{
AFFECTIVE VARIABLES IN A FOREIGN LANGUAGE IMMERSION PROGRAMME: A QUANTITATIVE STUDY
}

\author{
Marta del Pozo Beamud \\ Universidad de Castilla-La Mancha \\ marta.pozobeamud@uclm.es
}

\begin{abstract}
Language immersion has gained momentum within the last decades, as many learners around the word have benefitted from this motivating experience. Therefore, the principal aim of the present study was to ascertain whether a week of instruction at a linguistic immersion centre, whose language is English, has a positive influence on the levels of both intrinsic and extrinsic motivation, FL anxiety and the FL selves (Deci \& Ryan 2000, Dörnyei 2005, Horwitz, Horwitz and Cope 1991). Our participants were Primary education students (sixth graders; M: 11.5) who had taken part in such programme. They completed a quantitative questionnaire upon arrival ( $t 1)$ and before leaving ( $t 2)$. In order to compare their results both at time one and time at two one-factor ANOVA analysis was used. Results indicated that after the language learning inmersion programme experience, motivation increased, whereas anxiety decreased and the presence of the selves in the participants was weakened.
\end{abstract}

KEYWORDS: Affective variables, linguistic immersion, primary education.

\section{LAS VARIABLES AFECTIVAS EN UN PROGRAMA DE INMERSIÓN LINGÜÍSTICA: UN ESTUDIO CUANTITATIVO}

RESUMEN: La inmersión lingüistica ha cobrado mucha importancia durante las últimas décadas, ya que muchos estudiantes de todo el mundo se han beneficiado de esta experiencia tan motivadora. Por tanto, el objetivo principal de este estudio es determinar si una semana de inmersión en inglés tiene una influencia positiva en los niveles de motivación extrínseca e intrínseca, ansiedad en LE y los yoes en LE (Deci \& Ryan 2000, Dörnyei, 2005, Horwitz, Horwitz \& Cope 1991). Nuestros participantes son estudiantes de educación primaria (M: 11,5) que participaron en dicho programa. Estos cumplimentaron un cuestionario cuantitativo al llegar (test) y antes de terminar la semana (retest). Con el fin 
de comparar los resultados obtenidos en ambos momentos se utilizaron análisis ANOVA de un factor. Los resultados indicaron que después de la experiencia, la motivación aumenta, mientras que la ansiedad disminuye y la presencia de los yoes en los participantes se debilita.

PALABRAS CLAVE: variables afectivas, inmersión lingüistica, educación primaria.

\title{
VARIABLES AFFECTIVES DANS UN PROGRAMME D'IMMERSION LINGUISTIQUE : UNE ÉTUDE QUANTITATIVE
}

\begin{abstract}
RÉSUMÉ : L'immersion linguistique est devenue très importante au cours des dernières décennies, car de nombreux étudiants du monde entier ont bénéficié de cette expérience motivante. Par conséquent, le principal objectif de cette étude est de déterminer si une semaine d'immersion anglaise a une influence positive sur les niveaux de motivation extrinsèque et intrinsèque, l'anxiété en LE et les "selves" en l'EL (Deci et Ryan 2000, Dörnyei, 2005, Horwitz, Horwitz et Cope 1991). Nos participants sont des élèves du primaire (M: 11,5) qui ont participé au programme. Ils ont rempli un questionnaire quantitatif à l'arrivée (test) et avant la fin de la semaine (retest). Afin de comparer les résultats obtenus dans les deux cas, une analyse ANOVA d'un facteur a été utilisée. Les résultats indiquent qu'après l'expérience, la motivation augmente, tandis que l'anxiété diminue et que la présence des "selves" chez les participants s'affaiblit.

MOTS CLÉS : variables affectives, immersion linguistique, éducation primaire.
\end{abstract}

Recibido: 04/10/19. Aceptado: 08/05/20

\section{Introduction}

Nowadays, it is increasingly accepted that in order to understand the language learning process, the nature and impact of affective variables on this process must be taken into consideration. To a greater extent now, authors are adopting a more holistic approach with regard to understanding human cognitive processes, including how second or foreign languages are learnt. The context where learning takes place is also of great importance and currently there are numerous options from which a learner may choose. One of these options, that 
of immersion programmes, seems to be very popular since the learning of an L2 (second language) or FL (foreign language) takes place in a more natural way than in traditional methods. The main objective of this study was to examine how a foreign language immersion programme can influence an individual's affective variables (L2 motivation, L2 anxiety, L2 selves) and whether this influence is positive or not.

\subsection{Affective variables: L2 motivation, L2 anxiety and the L2 selves}

Krashen (1982), identified motivation as one of three affective variables, along with self-confidence and anxiety, which have considerable influence on the learning and/or acquisition of second languages. In the following definition by Menezes de Oliveira e Paiva (2011: 62), motivation is an essential element in any learning process: "Motivation is an important, complex subsystem nested in SLA systems, which works as a moving force in any learning process".

Foreign language anxiety is a situational anxiety, which may manifest itself within second or foreign language learning environments. Different authors have proposed different theories and models, one of the most important being that of Horwitz et al. (1991), in which he distinguished between three types of anxiety: communicative apprehension, exam anxiety and fear of negative evaluation. Communicative apprehension appears when the learner has to communicate orally in groups, in pairs or in public or when he or she hears or learns an oral message (Horwitz et al. 1991: 30). Exam anxiety is experienced by overly perfectionist learners with unrealistic goals; such students consider not doing an exam perfectly a failure (Horwitz et al. 1991: 30). Fear of negative evaluation could be considered even worse than exam anxiety. While test anxiety only appears when the learner faces exams, the fear of negative evaluation goes further and appears when the learner undergoes any type of assessment (Horwitz et al. 1991: 31).

In the L2 Motivational Self System, the motivation construct is integrated by the ideal L2 self, the ought-to L2 self and the L2 learning experience (Dörnyei 2005: 105). The ideal self, in this case, refers to the attributes that someone would like to possess in relation to learning a second language (Dörnyei 2005: 105). The ought-to self does not refer to the qualities that someone would like to have, but to the qualities that someone feels they should have (Dörnyei 2005: 105). The learning experience is integrated, in addition to the learner's own experience, by the elements of the student's own learning context (Dörnyei 2005: 106). 


\subsection{Affective variables and immersion programmes}

According to Cenoz, Genesee and Gorter (2014: 6), immersion is a type of educational programme in which instruction is carried out by means of a second or foreign language. In these programmes the instruction of non-linguistic content is carried out in a second language, known as CBI (Content-Based Instruction) (Cenoz et al. 2014, 6, 13). The Canadian model, with its inception in the 1960's, (Cenoz et al. 2014: 6) is groundbreaking and the most widely adopted to date. The majority of its students are Anglophone, in primary or secondary education who receive fifty percent of their instruction in French, in addition to other languages (Cenoz et al. 2014: 6). These types of programmes are currently available in many more countries, including Japan and the United States (Cenoz 2014: 7). With regard to North America, it should be noted that immersion is gaining in popularity and there are currently a total of 25 languages used in this type of programme (Cenoz et al. 2014: 9).

The effect of immersion programmes on the affective variables of participants is worth noting. In the case of motivation, it is often challenging to ascertain whether students are motivated because of the language programme itself or were already motivated prior to participation. (Cenoz et al. 2014: 14). Foster, Bolibauhg and Kotula (2014) demonstrated in their study of second language users of English both in the UK and in Poland, that immersion settings enhance motivation and "the earlier the better". In North America, Wesely (2009) found that six grade students who attended a French immersion school showed high levels of motivation. Tanaka and Kutsuki (2016) in Japan, discovered that immersion enhanced motivation in a sample of primary school students $(M=9.5)$.

Immersion programmes have been shown to be beneficial for those students suffering from foreign language anxiety. Baker and MacIntyre (2000: 333) in Canada, for example, demonstrated that immersion programmes were positive for their participants (adolescents between 14 and 18 years old). Grant (2018), in Macau, reported reduced anxiety levels in university students who participated in an immersion programme. Knell and Chi (2012), in China, found that immersion programmes translated in lower levels of anxiety amongst participants of 4th, 5th and 6th grades (primary school). In the Irish context, those students $(M=15.4)$ who joined an immersion school later, showed higher levels of anxiety (Ó Muircheartaigh and Hickey, 2008).

Finally, with regard to the selves, there is scant literature on the matter and the intention of this study was to try to shed some light on this area. Studies 
exploring the relationship between immersion and the affective variables are also scarce, relatively out of date and have been carried out outside Spain. Furthermore, the vast majority of studies examining affective variables have taken place within secondary school and university contexts. The present study aimed to fill this research gap by looking at a sample of primary school students in Spain.

\section{Method}

\subsection{Participants}

The number of participants in the test was 420 . These were sixth grade primary school children (average age: 11.5), who were involved in a one-week language immersion programme of the CRIEC (Rural Center for Educational Innovation in Cuenca) in the academic year 2015/2016. Almost $100 \%$ of the students attended public (state) schools. $59.4 \%$ attended bilingual schools, meaning that they were immersed in CLIL (Content and Language Integrated Learning) programmes, thereby learning a foreign language through non-linguistic subjects. The remaining $40.6 \%$ attended non-bilingual schools, where their exposure to English was limited solely to the subject of English. Male participants composed $54.2 \%$ of the sample and the vast majority of all participants were from rural or semi-rural backgrounds.

Since the CRIEC uses a CLIL approach, participants do not study English solely as a separate subject but rather, learn it through the delivery of other subjects. Moreover, the CRIEC offer a wide variety of activities such as workshops, movie viewings, or excursions with the English language as the medium of instruction. As Ruiz Cordero and Rodríguez Morales (2018) indicated, innovation in CLIL is a key element that marks the difference between this approach and more traditional methods of language teaching.

\subsection{Methodology}

The instrument used for the present study was developed and adapted to the participants' ages from other questionnaires (see Csizér and Kormos 2009, Gardner 2010, Horwitz 1983, Ryan 2009, Taguchi, Magid and Papi 2009). This instrument is a quantitative questionnaire in Spanish (students' mother tongue) consisting of twenty questions (Likert Scale 5) and four constructs (extrinsic 
motivation: items $3,8,12,19,20$; intrinsic motivation: $1,6,11,12,16$; FL Anxiety: 2, 9, 10, 14, 17; and the FL selves (ideal I: 4.18; and deontic I: 5, 7, 15), in addition to six personal questions designed to place participants in their socio-economic context and cultural (gender, school, family) (Appendix).

This instrument was submitted for scrutiny by a committee of experts in October 2015 and lead to the latest version. This committee of experts consisted of an educational psychologist, an expert in methodology, an expert in language learning and two primary school teachers. A validation guide was followed, evaluating the items in the questionnaire one by one in order to determine their relevance and suitability for children in sixth grade.

The questionnaire was then administered by teachers at the language immersion centre on the first and last days of the programme. Results were analysed, comparing levels of motivation, FL anxiety and participants' perception of their FL selves on both days.

\section{Analysis}

To ascertain whether or not the week of immersion had indeed had an effect on motivation and anxiety levels, in addition to the presence of the selves, it was considered appropriate to perform a one-factor ANOVA analysis. This was carried out with the objective of reducing our 20 items to a smaller number of factors. In addition, we were able to double check that the factors obtained (extrinsic motivation, intrinsic motivation, anxiety and the selves) coincided with the constructs that we had proposed a priori. Once these analyses had been completed, the means of each factor were calculated and to increase reliability of the analyses, the means for each of the items that make up the four factors were then calculated.

\section{Results}

Tables of results obtained, with the statistical significance of each item, are presented below. In Table 1, in the case of extrinsic motivation the means decrease in items 3 (I study English because I want to get good grades.) and 8 (I do my English homework when my teacher tells me to.) and increase in the rest of the items (13. I study English so that my parents are proud of me. / 19. I study English so that my teachers are proud of me. / 20. I think that English is a very important language.) The results are not, however, statistically significant $(\mathrm{p}<0.05)$. 
Table 1. ANOVA-Extrinsic motivation

\begin{tabular}{|c|c|c|c|c|c|c|}
\hline & & Sum of squares & Gl & Quadratic mean & $\mathbf{F}$ & Sig. \\
\hline \multirow[t]{3}{*}{ V03 } & Inter-groups & 4.506 & 1 & 4.506 & 3.009 & 0.083 \\
\hline & Intra-groups & 1158.854 & 774 & 1.497 & & \\
\hline & Total & 1163.360 & 775 & & & \\
\hline \multirow[t]{3}{*}{ V08 } & Inter-groups & 1.483 & 1 & 1.483 & 1.825 & 0.177 \\
\hline & Intra-groups & 628.148 & 773 & .813 & & \\
\hline & Total & 629.631 & 774 & & & \\
\hline \multirow[t]{3}{*}{ V13 } & Inter-groups & .785 & 1 & .785 & .422 & 0.516 \\
\hline & Intra-groups & 1450.043 & 779 & 1.861 & & \\
\hline & Total & 1450.827 & 780 & & & \\
\hline \multirow[t]{3}{*}{ V19 } & Inter-groups & 1.659 & 1 & 1.659 & .852 & 0.356 \\
\hline & Intra-groups & 1510.214 & 776 & 1.946 & & \\
\hline & Total & 1511.873 & 777 & & & \\
\hline \multirow[t]{3}{*}{ V20 } & Inter-groups & .489 & 1 & .489 & .496 & 0.481 \\
\hline & Intra-groups & 758.023 & 770 & .984 & & \\
\hline & Total & 758.512 & 771 & & & \\
\hline
\end{tabular}

Within the intrinsic motivation factor (table 2), the means decrease in the case of items 1 (I would like to travel to a country where English is spoken in order to learn it.) and 6 (I am interested in speaking English outside of school.). On the contrary, in the case of items 11 (I like to know things about the countries where English is spoken.), 12 (I like to watch films in English.) and 16 (I would like to know English to communicate with people who speak it.) the means increase. However, only the value obtained for item number 1 is significant. 
Table 2. ANOVA-Intrinsic motivation

\begin{tabular}{|c|c|c|c|c|c|c|}
\hline & & Sum of squares & GI & Quadratic mean & $\mathbf{F}$ & Sig. \\
\hline \multirow[t]{3}{*}{ V01 } & Inter-groups & 12.250 & 1 & 12.250 & 9.521 & 0.002 \\
\hline & Intra-groups & 998.454 & 776 & 1.287 & & \\
\hline & Total & 1010.704 & 777 & & & \\
\hline \multirow[t]{3}{*}{ V06 } & Inter-groups & 3.412 & 1 & 3.412 & 1.990 & 0.159 \\
\hline & Intra-groups & 1337.263 & 780 & 1.714 & & \\
\hline & Total & 1340.675 & 781 & & & \\
\hline \multirow[t]{3}{*}{ V11 } & Inter-groups & .181 & 1 & .181 & .120 & 0.729 \\
\hline & Intra-groups & 1170.846 & 775 & 1.511 & & \\
\hline & Total & 1171.027 & 776 & & & \\
\hline \multirow[t]{3}{*}{ V12 } & Inter-groups & .088 & 1 & .088 & .046 & 0.831 \\
\hline & Intra-groups & 1501.939 & 780 & 1.926 & & \\
\hline & Total & 1502.027 & 781 & & & \\
\hline \multirow[t]{3}{*}{ V16 } & Inter-groups & .360 & 1 & .360 & .347 & 0.556 \\
\hline & Intra-groups & 802.280 & 774 & 1.037 & & \\
\hline & Total & 802.639 & 775 & & & \\
\hline
\end{tabular}

Within the anxiety factor (Table 3), the means decrease in factors 2 (I find it hard to participate in English class because I am afraid of making mistakes.), 9 (It makes me nervous to speak English in class.), 14 (When I speak English in class I'm afraid that my classmates laugh at me.) and 17 (Going out to the board in English class causes me concern). In contrast, in item 10 (I get nervous when my English class starts.), there is an increase in the mean. The anxiety factor has three items whose means obtained are statistically significant (2, 9 and 17). 
Table 3. ANOVA-Anxiety

\begin{tabular}{|c|c|c|c|c|c|c|}
\hline & & Sum of squares & Gl & Quadratic mean & $\mathbf{F}$ & Sig. \\
\hline \multirow[t]{3}{*}{ V02 } & Inter-groups & 9.654 & 1 & 9.654 & 5.910 & 0.015 \\
\hline & Intra-groups & 1269.178 & 777 & 1.633 & & \\
\hline & Total & 1278.832 & 778 & & & \\
\hline \multirow[t]{3}{*}{ V09 } & Inter-groups & 27.230 & 1 & 27.230 & 14.590 & 0.000 \\
\hline & Intra-groups & 1444.585 & 774 & 1.866 & & \\
\hline & Total & 1471.814 & 775 & & & \\
\hline \multirow[t]{3}{*}{ V10 } & Inter-groups & .471 & 1 & .471 & .355 & 0.551 \\
\hline & Intra-groups & 1027.153 & 774 & 1.327 & & \\
\hline & Total & 1027.624 & 775 & & & \\
\hline \multirow[t]{3}{*}{ V14 } & Inter-groups & 5.799 & 1 & 5.799 & 3.337 & 0.068 \\
\hline & Intra-groups & 1344.994 & 774 & 1.738 & & \\
\hline & Total & 1350.793 & 775 & & & \\
\hline \multirow[t]{3}{*}{ V17 } & Inter-groups & 9.148 & 1 & 9.148 & 5.808 & 0.016 \\
\hline & Intra-groups & 1222.406 & 776 & 1.575 & & \\
\hline & Total & 1231.554 & 777 & & & \\
\hline
\end{tabular}

In the case of the selves (Table 4), the means drop in items 4 (In the future I will need my level of written English to be better.), 5 (In the future I would like to speak better in English.), 7 (In the future I would like to write better in English.) and 18 (Having a good level of oral English is important for my future.). However, in item 15 (In the future I want to understand English better.) the mean increases. In this selves factor, only the mean obtained in item 4 is statistically significant. 
Table 4. ANOVA-Selves

\begin{tabular}{|ll|c|c|c|c|c|}
\hline & & Sum of squares & Gl & Quadratic mean & F & Sig. \\
\hline V04 & Inter-groups & 6.505 & 1 & 6.505 & 5.933 & 0.015 \\
& Intra-groups & 847.528 & 773 & 1.096 & & \\
& Total & 854.034 & 774 & & & \\
\hline V05 & Inter-groups & 1.211 & 1 & 1.211 & 1.260 & 0.262 \\
& Intra-groups & 747.104 & 777 & .962 & & \\
& Total & 748.316 & 778 & & & \\
\hline V07 & Inter-groups & 1.498 & 1 & 1.498 & 1.313 & 0.252 \\
& Intra-groups & 886.287 & 777 & 1.141 & & \\
& Total & 887.784 & 778 & & & \\
\hline V15 & Inter-groups & .080 & 1 & .080 & .081 & 0.776 \\
& Intra-groups & 756.190 & 772 & .980 & & \\
& Total & 756.270 & 773 & & & \\
\hline V18 & Inter-groups & 2.448 & 1 & 2.448 & 2.996 & 0.084 \\
& Intra-groups & 633.933 & 776 & .817 & & \\
& Total & 636.380 & 777 & & & \\
\hline
\end{tabular}

\section{Discussion}

The results suggest that the week of immersion was positive in terms of both extrinsic and intrinsic motivation. These results are consistent with those obtained by Foster et al. (2014), Tanaka and Kutsuki (2016) and Wesely (2009), whose studies in Europe, North America and Asia respectively also found a positive correlation between immersion and motivation.

In the case of anxiety, the results were again positive since this was shown to have decreased after the immersion week. These results are in line with the work of Baker and MacIntyre (2000), Grant (2008) and Knell and Chi (2012) who also found that immersion programmes were effective in reducing students' levels of anxiety.

Regarding the selves, the results were not consistent with predictions since, after the week of linguistic immersion, it had been expected that both the oughtto self and the ideal self would have been reinforced through the activities carried out during the immersion week, as participants became more aware of 
the importance of English for their future both for external reasons (ought-to self) and for internal reasons (ideal self).

Thus, the CRIEC experience signified a turning point in the academic and personal life of our participants. Levels of both intrinsic and extrinsic motivation were shown to have increased following participation in the immersion programme. In other words, after this experience (the activities carried out and the good working environment that prevails in the center) participants were demonstrably more interested in language learning. In addition, these results are consistent with those of Mearns (2012: 176, 179, 181, 183), who demonstrated that the motivation of her participants, high school students between 13 and 14 years of age, increased after being part of a CLIL project that lasted six weeks. In the case of anxiety, Baker and MacIntyre (2000: 333) demonstrated that linguistic immersion was a positive experience for language learners since it reduced their anxiety. The present results seem to indicate that the presence of the selves is not reinforced after the immersion week. Contrary to our hypotheses, we cannot affirm that this experience of immersion in a bilingual centre with all that this entails has made respondents aware of the importance of English for their personal/academic present/future.

The results should, however, be considered with caution, since the only factor where a number of statistically significant differences were found was in that of anxiety. That is, it is indeed possible to state that the immersion experience can mitigate anxiety and its negative effects; as Saito and Samimi (1996) showed, anxiety can produce psychological, psycholinguistic and behavioral symptoms. Moreover, there are numerous studies which show a negative correlation between anxiety and academic achievement (Coulombe 2000; Gardner 2005). In other words, the more anxious an individual is, the worse their performance, implying that the absence of anxiety can facilitate improved academic results. Awareness of the negative effects of anxiety on second or foreign language learning has considerable implications for researchers and teachers. When a student obtains negative results, there is a tendency to assume that he or she lacks ability and or effort. However, it is clear that anxiety may be a factor in this process. Identifying the symptoms in students and attempting to minimise the negative impact that these may have on the learning process is clearly important, not only for teachers, but also for members of the wider educational community. Clavel and Martí (2008: 358) propose strategies such as laughter or deep breathing to relieve anxiety. Likewise, experiences such as a week of immersion provide a relaxed and pressure-free environment that undoubtedly reduces levels of anxiety in students. 
Such programmes should be considered for mandatory implementation in at least primary education and students should be offered not only the opportunity to participate in such programmes but also be actively encouraged to participate in them thereby increasing their learning potential.

\section{Conclusion}

Results suggest that the immersion programme had a positive effect on the affective variables of the participants, specifically, respondents' motivation and the selves, in addition to a reduction in levels of anxiety. Although not all the results were statistically significant, it is possible that the implementation of other quantitative statistical techniques such as the T-test or Mann-Whitney U Test may have yielded different results and this should be considered in terms of future research. Follow-up interviews of a qualitative nature may have yielded interesting results too, since when analysing affective variables such instruments as these are useful (Ushioda, 2012). Another possible future research initiative would be to replicate the study at other bilingual centres in other regions and/ or countries. We are aware that a week of immersion may be considered a short period of time, but it was the stipulated duration of this particular programme.

There are various pedagogical implications arising from our study, for example, the importance of teachers' awareness of the role of affective variables in language learning, the positive effect of motivation and the selves and the detrimental effect of anxiety in this process. Our study also suggests that in order to facilitate the fulfillment of their language learning potential, all language learners should be given the opportunity to participate in language immersion programmes.

\section{References}

BAKER, S. C. and MACINTYRE, P. D. (2000). "The role of gender and immersion in communication and second language orientations". Language Learning 50(2): 311-341.

BALE ROCA, S. B. (1980). "Applied linguistic, method and objectives in language teaching". Cuadernos de investigación filológica (6): 53-62.

BARCELOS, A. M. F. (2015). "Unveiling the relationship between language learning beliefs, emotions and identities". Studies in Second Language Learning and Teaching 5(2): 301-325. 
CENOZ, J., GENESEE, F. and GORTER, D. (2014). "Critical analysis of CLIL: Taking stock and looking forward". Applied linguistics 35(3): 243-262.

CLAVEL, B. and MARTÍ, M. M. (2008). "Second Language Acquisition". In Working with words: An introduction to English linguistics. (Eds. M. Fuster and A. Sánchez). Universitat de Valéncia: Publicacions Universitat de Valéncia: 331-365.

COULOMBE, D. (2000). "Anxiety and beliefs of French-as-a-second-language learners at the university level". Unpublished doctoral dissertation, University of Laval, Quebec, Canada.

CSIZÉR, K. and KORMOS, J. (2009). "Learning experiences, selves and motivated learning behaviour: A comparative analysis of structural models for Hungarian secondary and university learners of English". In Motivation, language identity and the L2 self. (Eds. Z. Dörnyei and E. Ushioda). Bristol: Multilingual Matters: 98-119.

DECI, E. L. and RYAN, R. M. (2000). "The 'what' and 'why' of goal pursuits: Human needs and the self-determination of behavior". Psychological Inquiry 11(4): 227-268.

DEWEALE J. M. (2011). "Reflections on the emotional and psychological aspects of foreign language learning and use". Anglistik: International Journal of English Studies 22(1): 23-42.

DÖRNYEI, Z. (2005). The psychology of the language learner: Individual differences in second language acquisition. Mahwah, NJ: Lawrence Erlbaum.

DÖRNYEI, Z. (2009). "The L2 motivational self system". In Motivation, language identity and the L2 self. (Eds. Z. Dörnyei and E. Ushioda). Bristol: Multilingual Matters: 9-42.

DÖRNYEI, Z. and USHIODA, E. (2011). Teaching and researching motivation (2nd edition). Harlow: Pearson.

GARDNER, R. C. (2005). "Integrative Motivation and Second Language Acquisition". http://publish.uwo.ca/wgardner/caaltalk5final.pdf (Accessed 01/04/2007).

GARDNER, R. C. (2010). Motivation and second language acquisition: The socio-educational model. New York, NY: Peter Lang Publishing.

GARRET, P. and YOUNG, R. (2009). "Theorising affect in foreign language learning: An analysis of one learner's responses to a communicative Portuguese course". The Modern Language Journal 93(2): 209-226.

GRANT, S. (2018). "Effects of intensive EFL immersion programmes on willingness to communicate". The language learning journal 46(1): 1-12.

FOSTER, P., BOLIBAUGH, C. and KOTULA, A. (2014). "Knowledge of 
nativelike selections in a L2: The influence of exposure, memory, age of onset, and motivation in foreign language and immersion settings". Studies in Second Language Acquisition 36(1): 101-132.

HORWITZ, E. K. (1983). Foreign language classroom anxiety scale. Unpublished manuscript.

HORWITZ, E. K. et al. (1991). "Foreign language classroom anxiety". In Language anxiety: From theory and research to classroom implications. (Eds. E. K. Horwitz and D. J. Young). Upper Saddle River, NJ: PrenticeHall: 27-36.

KNELL, E., and CHI, Y. (2012). "The roles of motivation, affective attitudes, and willingness to communicate among Chinese students in early English immersion programs". International Education 41(2): 5.

KRASHEN, S. D. (1982). Principles and practice in second language acquisition. Oxford: Pergamon Press.

MEARNS, T. L. (2012). "Using CLIL to enhance pupils' experience of learning and raise attainment in German and health education: A teacher research project". The Language Learning Journal 40(2): 175-192.

MENECES DE OLIVEIRA E PAIVA, V. L. (2011). "Identity, motivation and autonomy in second language acquisition from the perspective of complex adaptive systems". In Identity, motivation and autonomy in language learning. (Eds. G. Murray et al.). Bristol: Multilingual Matters: 57-72.

Ó MUIRCHEARTAIGH, J. and HICKEY, T. (2008). "Academic outcome, anxiety and attitudes in early and late immersion in Ireland".International Journal of Bilingual Education and Bilingualism 11(5): 558-576.

RYAN, S. (2009). "Self and identity in L2 motivation in Japan: The ideal L2 self and Japanese learners of English". In Motivation, language identity and the L2 self. (Eds. Z. Dörnyei and E. Ushioda). Bristol: Multilingual Matters: 120-143.

SAITO, Y. and SAMIMY, K. K. (1996). "Foreign language anxiety and language performance: A study of learner anxiety in beginning, intermediate, and advanced-level college students of Japanese". Foreign Language Annals 29(2): 239-249.

TAGUCHI, T., MAGID, M. and PAPI, M. (2009). "The L2 motivational self system among Japanese, Chinese and Iranian learners of English: A comparative study". In Motivation, language identity and the L2 self. (Eds. Z. Dörnyei and E. Ushioda). Bristol: Multilingual Matters: 66-97.

TANAKA, Y. and KUTSUKI, A. (2018). "Motivation for learning English in the immersion environment of an international school in Japan". 
International Journal of Bilingual Education and Bilingualism 21(6): 729-743.

USHIODA, E. (2012). “Motivation: L2 learning as a special case?”. In Psychology for Language Learner. (Eds. S, Mercer, S. Ryan, and M. Williams). Houndmills: Palgrave MacMillan: 58-73.

WESELY, P. M. (2009). "The language learning motivation of early adolescent French immersion graduates”. Foreign Language Annals 42(2): 270-286. 


\section{UCLM}

\section{Departamento de Filología Moderna. Facultad de Educación, CUENCA}

Contesta a las siguientes preguntas personales.

Sexo: $\mathrm{M}$

Colegio:

¿Es bilingüe? Sí

¿Algún miembro de tu familia habla inglés? $\mathrm{S} \square \mathrm{NQ}$

Profesión del padre:

Profesión de la madre:

Contesta a las siguientes preguntas sobre el INGLÉS EN TU COLEGIO. Para cada pregunta elige uno de los siguientes emoticonos. (Likert scale del 5 al 1)

:-D-Totalmente de acuerdo

-)-De acuerdo

- -Ni de acuerdo ni en desacuerdo

:-)-En desacuerdo

$>$ :(-Totalmente en desacuerdo

1. Me gustaría viajar a un país donde se hable inglés para poder aprenderlo. :-D $;)(:)<:$

2. Me cuesta participar en clase de inglés porque tengo miedo a cometer errores. :-D $\odot ;) ;<:($

3. Estudio inglés porque quiero sacar buenas notas. :-D $;: ;<<:($

4. En el futuro necesitaré que mi nivel de inglés escrito sea mejor. :-D $;-;)<<:($

5. En el futuro me gustaría hablar mejor en inglés. :-D $;:) ;<:($

6. Tengo interés en hablar inglés fuera del colegio. :-D $; ;) ;<:($

7. En el futuro me gustaría escribir mejor en inglés. :-D $;:) ;<:($

8. Hago las tareas de inglés cuando me las manda el profesor. :-D $;:) ;<:($

9. Me pone nervioso hablar inglés en clase. :-D $;-;) ;<:($

10. Me pongo nervioso al empezar la clase de inglés. :-D $; * ;<<:($

11. Me gusta saber cosas sobre los países donde se habla inglés. :-D $\odot ;) ;<:($

12. Me gusta ver películas en inglés. :-D :) :- :)<:(

13. Estudio inglés para que mis padres estén orgullosos de mí. :-D $;() ;<<$ :)

14. Cuando hablo inglés en clase tengo miedo de que mis compañeros se rían de mí. :-D $\odot ;) ;<:($

15. En el futuro quiero entender mejor el inglés. :-D $; ;) ;<<($

16. Me gustaría saber inglés para comunicarme con personas que lo hablan. :-D $\odot ;) ;<:($

17. Salir a la pizarra en clase de inglés me causa preocupación. :-D $;-;<<:($

18. Tener un buen nivel de inglés oral es importante para mi futuro. :-D $\odot ;) ;<:($

19. Estudio inglés para que mis profesores estén orgullosos de mí. :-D $\odot ;) ;<<$ : (

20. Pienso que el inglés es una lengua muy importante. :-D $;-;<<:($ 
จUCLM

Departamento de Filología Moderna. Facultad de Educación, CUENCA

Answer the following personal questions.

Sex: $\mathrm{M}$

$F$

School:

Is it bilingual? Yes $\square$ No

Does any member of your family speak English? Yes $\square$ No $\square$

Father's job:

Mother's job:

Answer the following questions about ENGLISH IN YOUR SCHOOL.

For each question choose one of the following emoticons.

:-D-Totally agree

-:-Agree

$\odot-$-Neither agree nor desagree

:-Disagree

$>:(-$ Totally disagree

1. I would like to travel to a country where English is spoken in order to learn it. :-D $;)(-)<:($

2. I find it hard to participate in English class because I am afraid of making mistakes.:-D $\odot ;) ;<:($

3. I study English because I want to get good grades. :-D $\odot ; ;)<<:($

4. In the future I will need my level of written English to be better. :-D $; ;) ;<:($

5. In the future I would like to speak better in English. :-D $; ;) ;<:($

6. I am interested in speaking English outside of school. :-D $;) ;<<:($

7. In the future I would like to write better in English. :-D $; * ;<<:($

8. I do my English homework when my teacher tells me to. :-D $;) ;(;)<:($

9. It makes me nervous to speak English in class. :-D $;) ;<<:($

10. I get nervous when my English class starts. :-D $;:-;<<:($

11. I like to know things about the countries where English is spoken. :-D $\odot ;) ;<:($

12. I like to watch films in English. :-D $;:) ;<:($

13. I study English so that my parents are proud of me. :-D $;) ;<:($

14. When I speak English in class I'm afraid that my classmates laugh at me. :-D $\odot ;) ;<:($

15. In the future I want to understand English better. :-D $;:) ;<:($

16. I would like to know English to communicate with people who speak it. :-D $;) ;<<:($

17. Going out to the board in English class causes me concern. :-D :) $;:<<:($

18. Having a good level of oral English is important for my future. :-D $\odot ;) ;<$ : ()$^{-}$

19. I study English so that my teachers are proud of me. :-D $; * ;<<:($

20. I think that English is a very important language. :-D $\odot ;<<:($ 